DOI https://doi.org/10.18551/rjoas.2018-08.12

\title{
EFFECT OF PROFITABILITY, LEVERAGE TOWARD DIVIDEND POLICY AND FIRM VALUE
}

\author{
Sugiastuti R.H.* \\ Post-graduate Program, Faculty of Administrative Science, University of Brawijaya, \\ Indonesia
}

Dzulkirom M., Rahayu S.M.

Faculty of Administrative Science, University of Brawijaya, Indonesia

*E-mail: ree.happy.s@gmail.com

\begin{abstract}
This study was aimed to describe the relationship between profitability and leverage toward dividend policy and firm value. This study was conducted toward 15 banking firms registered in Indonesia Stock Exchange with data analysis using Partial Least Square. Result of this study showed that profitability has significant effect toward dividend policy; however, on the other hand, profitability has insignificant and negative effect toward firm value. Concerning leverage, this study showed that leverage in banking firms has significant effect toward dividend policy but it shows insignificant and negative effect toward firm value.
\end{abstract}

\section{KEY WORDS}

Profitability, leverage, dividend policy, firm value.

Rapid change in global economy condition has affects the economy of most countries, particularly Indonesia. Global event experienced by United States of America in 2008 has influence the capital market in Indonesia. During global crises in 2008 has shown lower performance of Indonesia Composite Index (IHSG) since August 2008 (www.kompasiana.com). Lower performance of Indonesia Composite Index occurs because several foreign investors has withdrawn their investment in Indonesian firms. These capital withdrawals creates capital change within the firm and would affect firm's performance. Strict business competition in Indonesia was also triggered by the large number of firms operated in Indonesia. It can be seen by 532 registered go public firms in Indonesia Stock Exchange $(B E I / I D X)$ in 2016. These firms were listed in 9 sectors, such as sector (1) agriculture, (2) mining, (3) basis industry and chemical, (4) various industry, (5) household industry (manufacture), (6) real estate properties and building construction, (7) utility infrastructure and transportation, (8) finance and (9) trade, service and investment. This condition demand clever business actors to develop their business strategy and policies. Precise and suitable business strategy and policies was aimed to improve firms' performance so that it can survive and compete in domestic and international market.

Good firm's performance would identical with stable and improved finance performance, according to Margaretha (2014) finance performance is one way to evaluate firm's efficiency and effectiveness in producing profit and certain cash position. Firms with higher profit were assumed by investors as in a good condition (Winarto, 2015). Improved finance performance was also seen as the sign about firm's profitability. Profitability is the ability of firms in producing profit through all of its activities and its resources management within certain period of time. Firm's activities and management can take forms in sales, asset utilization, and capital utilization (Hery, 2016).

Higher profitability would affect higher firm's return and thus higher dividend payment (Abreu and Gulamhussen, 2013). This statement support the Signalling theory by Bhattacharya (1979), when profit obtained by firm was on target or even above the target, it means that those revenues would facilitate the firm in paying its dividend toward its shareholders. Firm that paid higher dividend would attract other investors to invest in the 
firm. Studies concerning Profitability and Dividend Policies were studies conducted by Abreu and Gulamhussen (2013), Lestari (2012), Javed (2012), Ameer (2008) and Hamid et al., (2016) which suggest that firm's profitability has positive and significant effect toward dividend policies.

Other than investment from investors, other firm's resources is leverage, according to Brigham and Houston (2010) firms would focus more on financing by using debt. Go public firms would already use debt as its capital supplement to expand their business for their future survival. Every year, firm's shareholder (investors) expects profit sharing given toward shareholder. Go public firm's profit sharing would be related to a policy known as dividend policy. This dividend policy (Horne and Wachowicz, 2007) was an accurate profit allocation arrangement for the profit obtained by the firm, whether it would be divided in the form of dividend or would it be retained for firm's survival in the future. In this study, author would focus on the profitability and leverage variables in influencing dividend policy, because both variables has direct relationship with firm's finance condition. Good firm value was also another objective in establishing a firm.

Firm value was also assumed as the measure in assessing performance success of a firm. Firm value according to Gitman (2006) was the actual amount per share of common stock that would be received if all the firm's assets were sold for their market value. According to Miller Modigliani in Margaretha (2014), he suggest that dividend policy was not relevant with firm value, this was because firm value was not determined by high or low dividend payment. Several previous paper from Siboni and Pourali (2015), Winarto (2015), and Kim et al. (2016) suggest that suitable and appropriate dividend policies would show positive effect toward firm value, and thus author was attracted to study about research gap concerning effect of dividend policy toward firm value. Study by Winarto (2015) suggests that profitability has positive and significant effect toward firm value. Study by Gupta et al. (2016) suggest that finance leverage did not related with firm value while study by Gill and Obradovich (2012) suggest that leverage has positive effect toward firm value. Based on the differences in previous study's results, author would like to study the effect of profitability and leverage toward dividend policies and firm value.

The existence of firms operated in Indonesia was highly various and they lies in different sectors, such as firms in banking sector. Banking sector in Indonesia was assumed to be the most important element in the economy. Bank was highly related with the life of the people because banking sector was involved in financing commercial firms and provide finance services. Banking sector is the service institution which collect funds from the people in the form of deposits and than redistribute it to the people in the form of credit/loan. Therefore, banking sector was seriously in need of lots of funds. Funds from the third party such as those in the form of deposits would be recorded as liability, and higher liability in banking firms would enable business fluency and improved profit growth because credit distribution was liable to interest rate by the bank which then received and recorded as bank's income (profit). This describe that banking firms, different than other type of firms, has high leverage level and enable higher profit in the future. However, according to Hery (2016) which suggest that high leverage level would disrupt growth and profit obtained because it use more debt with higher risk. This difference in opinion has become another attraction for further study in banking sectors firms.

\section{LITERATURE REVIEW}

Firm's profitability is the important factor within the firm because it shows profit obtained by firm's management (Hery, 2016). Generally speaking, a firm can be said success if it was able to create profit from higher revenue than the cost for its business activities, Abreu and Gulamhussen (2013), Lestari (2012) and Asad and Yousaf (2014). Higher profitability showed future firm's prospect was very good and thus investors would assumed this as a positive sign to invest in it, Javed (2012). Investors expect that with higher profitability, it has higher dividend. This showed that,

$\mathrm{H}_{1}$ : Profitability has significant effect toward dividend policy. 
Future prospect of firm value would also increase along with higher profitability level, Winarto (2015). This condition showed that higher profitability firms has good firm performance and creating positive perception for investors and thus increasing their firm's stock value in the capital market. Increasing stock market price would increase firm value. This showed that,

$\mathrm{H}_{2}$ : Profitability has significant effect toward firm value.

Leverage is the firm's ability to pay debt in which this debt would be use by firm as capital supplement, Asad and Yousaf (2014). This debt would cause fix load in the form of interest rate that should be paid by the firm. Debt received by the firm was the obligation that should be paid by the firm, Asif et al., (2011). Debt proportion in the firm was related and influence dividend policies, whereas firm with higher debt would help and support the firm in running its business activities but also has higher risk, Ameer (2008). Higher debt would decrease firm's prodit because firm was force to used its profit in paying its debt than paying dividend, Hamid et al. (2016). This condition has become firm's consideration to determine the appropriate proportion related to debt and dividend policy, because debt has negative relationship toward dividend policy.

$\mathrm{H}_{3}$ : Leverage has significant effect toward dividend policy.

Leverage or the ability of the firm to pay its debt would not only affect the dividend policy, but also affect firm value, Winarto (2015). If the proportion of firm's debt was high then the risk bear by the firm (related with firm's ability) would also high and it would affect public perception regarding firm value, Gupta et al., (2016) and Gill and Obradovich (2012). This showed that,

$\mathrm{H}_{4}$ : Leverage has significant effect toward firm value.

Subsequent focus in this study was to test the effect of dividend policy toward firm value. Dividend policy is the decision concerning whether profit obtained by the firm would be divided toward shareholders or it would be used as retained profit to finance future survival of the firm, Siboni and Pourali (2015). Dividend payment is the allocation of firm's profit toward shareholders, Kim et al. (2016). Decision to pay dividend toward investors with higher proportion means that firm retain lower profit and vice versa, if it give lower proportion of dividend then it means the firm retain higher profit, Winarto (2015). This condition would lower people's perception and thus lowering the assessment for the firm.

$\mathrm{H}_{5}$ : Dividend policy has significant effect toward firm value.

\section{METHODS OF RESEARCH}

This study was an explanatory research. Explanatory research is research or study aimed to describe the stands of the studied variables and also the correlation of one variable toward another (Sugiyono, 2007). This study would give causal explanation or causal relationship between profitability, leverage, dividend policy and firm value variables through hypotheses testing. Author conduct study in registered banking sector in Indonesia Stock Exchange (BEI/IDX) 2013-2016 period, with data taken from the Corner of Indonesia Stock Exchange (Pojok Bursa Efek Indonesia) or through Indonesia Stock Exchange (IDX). The reason behind site selection was because the necessary data was already available in the Corner of Indonesia Stock Exchange and can be accessed through www.idx.co.id. This study used sampling determination technique with purposive sampling or judgment sampling. Purposive sampling describe the selected samples based on its assessment toward several characteristics of sample's members adjusted with author's intention (Kuncoro, 2013) to obtain representative sample in accordance with predetermined criteria. In purposive sampling technique, author used considerations by creating boundaries or certain criteria based on the subject's features. Several criteria used to select study sample were:

- Banking firms was registered continuously in Indonesia Stock Exchange during study period of 2013-2016. Selecting 2013-2016 periods with 4 years worth of data was considered to be sufficient by the author. Selecting longer term data would lessen the number of firm because several firms cannot continuously registered in IDX for long period of time. 
- Banking firms that always publish their full annual report and that has been audited during study period of 2013-2016.

- Banking firms stated "healthy" in 2016, in which this decision was based on the letter of Bank Indonesia (BI) No 6/23/DNNP of 2004.

- Banking firms that has paid dividend at leas once during the study period of 20132016.

Based on the population of 44 banking firms listed in Indonesia Stock Exchange for four years, we obtain 15 firms that meet the requirement to be used as samples in this study. Thus, number of sample based on the predetermined criteria consists of 60 observation data (15 firms $x 4$ year). And then, to measure profitability in this study we use 3 profitability ratios such as:

Return on Assets (ROA):

\begin{tabular}{||c||}
\hline \hline ROA $=\frac{\text { earning after interest and taxes }}{\text { total assets }} \times 100 \%$ \\
\hline
\end{tabular}

Return on Equity (ROE):

$$
R O E=\frac{\text { Earning after Interest and Tax }}{\text { Total Equity }} \times 100 \%
$$

Earnings per Share (EPS):

$$
\text { EPS }=\frac{\text { Common stock profit }}{\text { circulated common stock }}
$$

Leverage variable showed the ability of firm in paying the debt of a firm. This variable was measured with two indicators consist of:

Debt to Asset Ratio:

\begin{tabular}{||c||}
\hline Debt to asset ratio $(D A R)=\frac{\text { Total Liabilities }}{\text { TotalAssets }}$ \\
\hline
\end{tabular}

Debt to Equity Ratio:

\begin{tabular}{||l|l|l}
\hline \hline \\
DER $=\frac{\text { Total Liabilities }}{\text { TotalEquity }}$
\end{tabular}

Dividend policy was related with how much cash that should be paid toward shareholders. Optimum firm's dividend policy was the policy that creates balance between dividend with retained profit for the future growth and development of the firm. Dividend policy variable can be measured with 2 observed ratio:

Dividend Payout Ratio (DPR):

$$
\text { DPR }=\frac{\text { DividendPerShare }(D P S)}{\text { Earning perShare }(E P S)} \times 100 \%
$$

Dividend per Share (DPS): 
Firm value is the measurement of management success in managing firm's operational activities so that it can be better and attract new shareholders or new investors. Below presented 2 indicators selected to measure firm value in this study:

Price Earnings Ratio (PER):

$$
\mathrm{PER}=\frac{\text { Price per share }}{\text { Earning per share }}
$$

Price to Book Value (PBV):

$$
P B V=\frac{\text { Share price }}{\text { Book Value of Share }}
$$

Data analysis technique in this study was using Partial Least Square (PLS) method with smart PLS software. Data analysis technique with PLS was considered to be suitable because variables relationship model was highly complex with small number of data sample. Based on the relationship developed in this study, concept model can be described in Figure 1 below:

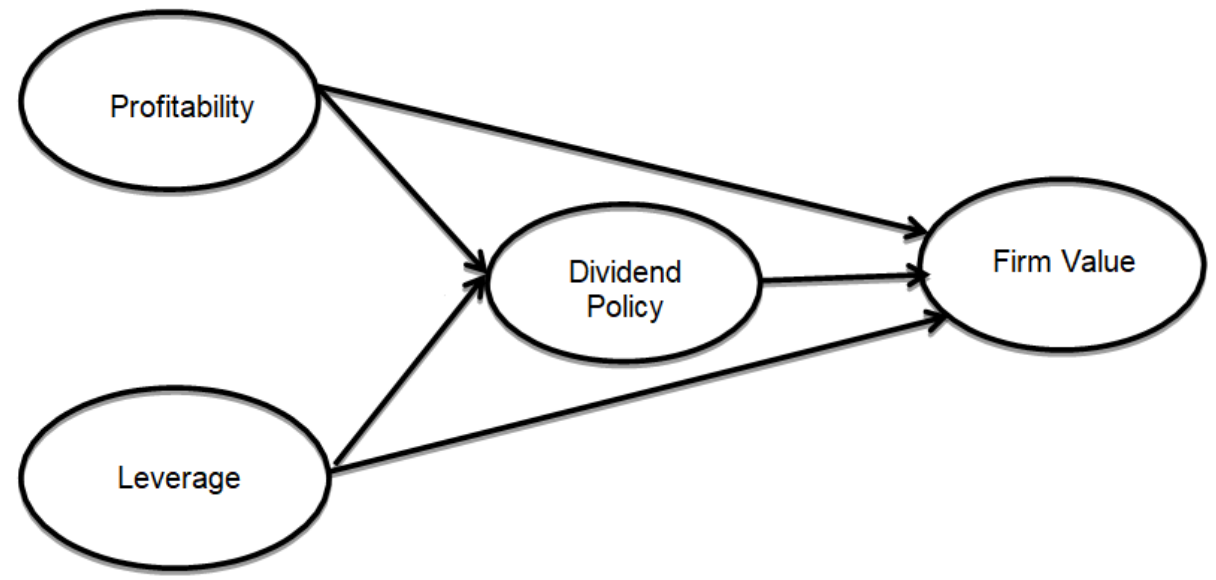

Figure 1 - Conceptual Model

\section{RESULTS AND DISCUSSION}

Below presented results summary of Partial Least Square (PLS) technique initiated with outer model analysis:

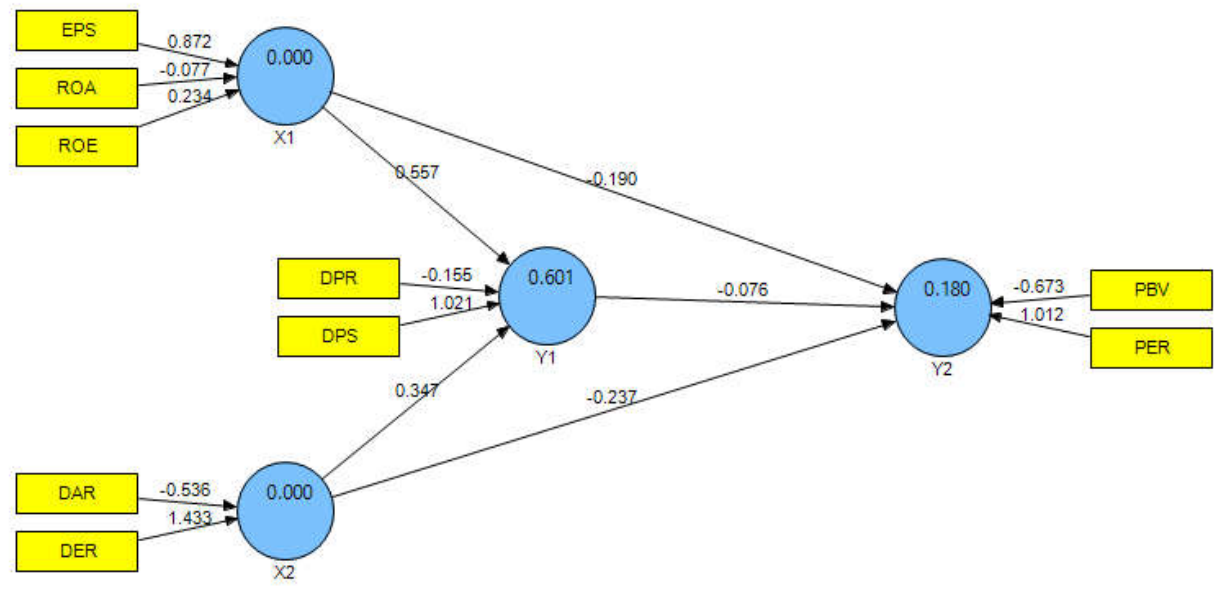

Figure 2 - PLS Outer Model 


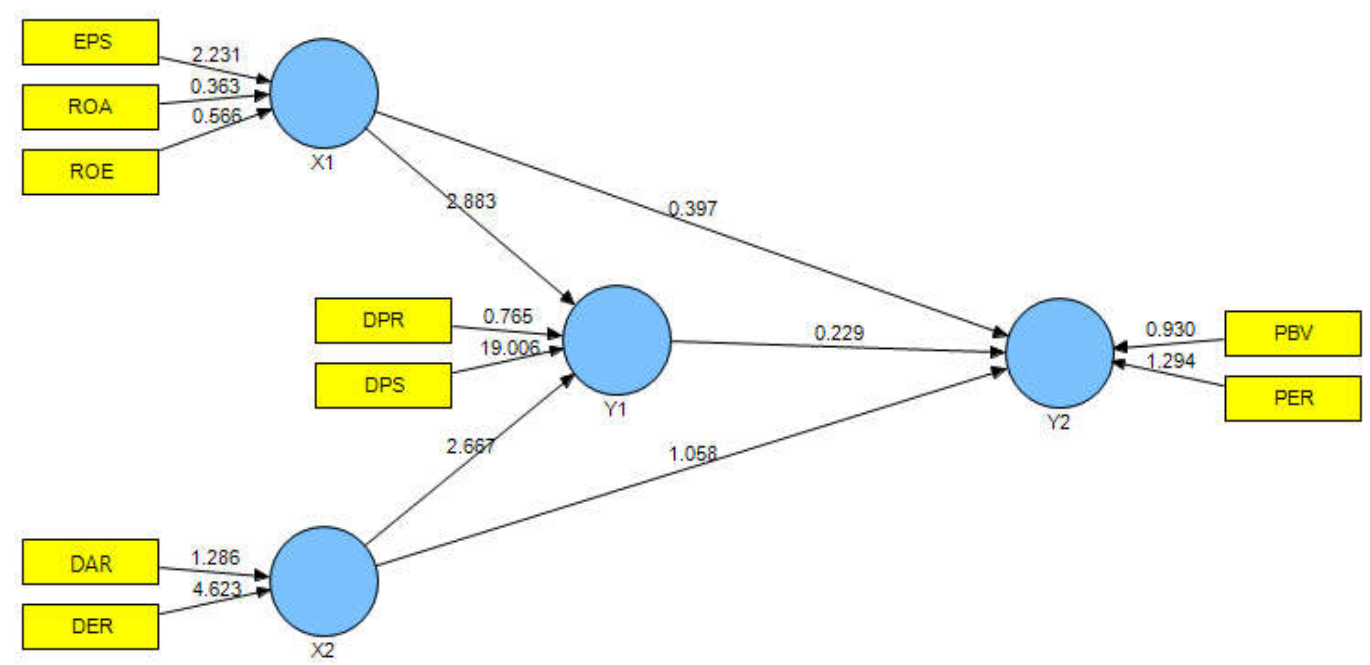

Figure 3 - PLS Inner Model

In PLS, statistical testing over each hypothesized relationship was done through simulation. In this matter, bootstrap method was done toward samples. Bootstrap testing was also meant to minimize abnormality problem for the data. Study results by bootstrapping from PLS analysis were given below:

Table 1 - Path Coefficient (Mean, STDEV, T-Values)

\begin{tabular}{|l|l|l|l|}
\hline Variables Relationship & $\begin{array}{l}\text { Original } \\
\text { Sample (O) }\end{array}$ & $\begin{array}{l}\text { Standard } \\
\text { Deviation (STDEV) }\end{array}$ & $\begin{array}{l}\text { T Statistics } \\
\text { (O/STERR) }\end{array}$ \\
\hline Profitability -> Dividend Policy & 0.5566 & 0.1930 & 2.8833 \\
\hline Profitability -> Firm Value & -0.1896 & 0.4775 & 0.3971 \\
\hline Leverage ->Dividend Policy & 0.3468 & 0.1301 & 2.6666 \\
\hline Leverage -> Firm Value & -0.2373 & 0.2243 & 1.0582 \\
\hline Dividend Policy -> Firm Value & -0.0764 & 0.3330 & 0.2293 \\
\hline
\end{tabular}

Source: PLS data processing, 2018.

Based on Table 1, we obtained results as follows:

$$
\begin{gathered}
Y_{1}=0,5566 X_{1}+0.3468 X_{2} \\
Y_{2}=-0,1896 X_{1}-0,2373 X_{2}-0,0764 Y_{1}
\end{gathered}
$$

Hypothesis Testing:

The first result of hypothesis testing showed that relationship between Profitability (X1) and Dividend Policy (Y1) shows path coefficient value of 0,5566 with $t$ value of 2,8833 . This value was higher than $t$ table $(1,960)$. This means that Profitability has positive and significant effect toward Dividend Policy and thus in accordance with the first hypothesis which suggest that Profitability has significant effect toward Dividend Policy. This means Hypothesis 1 is accepted.

Second result of hypothesis testing showed that relationship between Profitability (X1) and Firm Value (Y2) shows path coefficient value of $-0,1896$ with $t$ value of 0,3971 . This value was smaller than $t$ table $(1,960)$. It means that Profitability has negative and insignificant effect toward Firm Value. This is inappropriate with the second hypothesis which suggests that Profitability has significant effect toward Firm Value. This means Hypothesis 2 is rejected.

Third result of hypothesis testing showed that relationship between Leverage (X2) and Dividend Policy (Y1) shows path coefficient value of 0,3468 with $t$ value of 2,6666. This value was higher than t table $(1,960)$. It means that Leverage has positive and significant effect toward Dividend Policy, in accordance with the hypothesis which suggests that Leverage has significant effect toward Dividend Policy. This means Hypothesis 3 is accepted. 
Fourth result of hypothesis testing showed that relationship between Leverage (X2) and Firm Value (Y2) shows path coefficient value of $-0,2373$ with $t$ value of 1,0582 . This value was smaller than $t$ table $(1,960)$. It means that Leverage has negative and insignificant effect toward Firm Value. This is inappropriate with the fourth hypothesis which suggests that Leverage has significant effect toward Firm Value. This means Hypothesis 4 is rejected.

Fifth result of hypothesis testing showed that relationship between Dividend Policy (Y1) and Firm Value (Y2) shows path coefficient value of $-0,0764$ with $t$ value of 0,2293 . This value was smaller than $t$ table $(1,960)$. It means that Dividend Policy has negative and insignificant effect toward Firm Value. This is inappropriate with the fifth hypothesis which suggests that Dividend Policy has significant effect toward Firm Value. It means Hypothesis 5 is rejected.

Table 2 - Indirect Effect

\begin{tabular}{|l|l|l|l|l|l|l|l|}
\hline Variables & \multicolumn{2}{|l|}{ Direct Coefficient } & \multicolumn{2}{l|}{ Error standard } & Indirect Coeff. & se Gab & t calculated \\
\hline $\mathrm{X} 1, \mathrm{Y} 1, \mathrm{Y} 2$ & 0.5566 & -0.0764 & 0.1930 & 0.3330 & -0.043 & 0.197 & -0.216 \\
\hline $\mathrm{X} 2, \mathrm{Y} 1, \mathrm{Y} 2$ & 0.3468 & -0.0764 & 0.1301 & 0.3330 & -0.026 & 0.124 & -0.214 \\
\hline
\end{tabular}

Source: Processed data, 2018.

Based on Table 2 above, we can see the indirect effect were as follows: Results showed that relationship between Profitability (X1) and Firm Value (Y2) through Dividend Policy (Y1) shows indirect path coefficient value of 0,043 with $t$ value of 0,216 . This value was smaller than $t$ table $(1,960)$. This result shows that Dividend Policy has insignificant effect in mediating Profitability toward Firm Value.

Result also showed that relationship between Leverage (X2) and Firm Value (Y2) through Dividend Policy (Y1) shows indirect path coefficient value of $-0,026$ with $t$ value of 0,214 . This value was smaller than $t$ table $(1,960)$. It means Dividend Policy has insignificant effect in mediating Leverage toward Firm Value.

\section{CONCLUSION}

Several things can be concluded in this study. These results were in accordance with suggestion of Tampubolon (2013) that Profitability is one of the factors that affects Dividend Policy. Results in this study also in accordance with previous study of Abreu and Gulamhussen (2013), Lestari (2012), Asad and Yousaf (2014), Javed (2012), Ameer (2008) and Hamid et al. (2016) which suggest that Profitability has positive and significant effect toward Dividend Policy.

Results from other studies also suggest that Profitability has negative and insignificant direct effect toward Firm Value. Results in here did not support previous study of Winarto (2015) which suggest that Profitability has positive and significant effect toward Firm Value. This study also showed that Leverage variable has significant effect toward Dividend Policy variable. Positive path coefficient value means that every increase of Leverage reflected in Debt to Asset Ratio (DAR) and Debt to Equity Ratio (DER) would increase Dividend Policy reflected in Dividend per Share (DPS) and Dividend Payout Ratio (DPR).

Results of this study also showed that Leverage did not have significant effect toward Firm Value and has a negative path coefficient value. This means that Leverage ratio in the firm did not influence firm value and shown with negative path coefficient value. This might occurs because in banking firms, high Leverage was necessary and it did not change public view of firm value and therefore high Leverage wouldn't affect firm value.

This study also showed that Dividend Policy in the firm did not have significant effect toward firm value and was shown in negative path coefficient value. This means that Dividend Policy ratio in the firm did not affect investor's view about the firm, and reflected in negative path coefficient value. Therefore, even if there was low Dividend Policy in the firm, Firm Value would still adequate. This might be because among banking firms there were several firms that did not pay dividend for several years during our study period and they tend to retain their profit for business development and to strengthening capital structure 
within the firm, although these would not affect public perception concerning this. Thus, dividend policy did not affect firm value and it has negative path coefficient value.

Limitation of research:

- Study period in this research was limited in 4 years worth of data, started with 2013 to 2016;

- This study was only use samples and did not use different firms in comparison. It only use banking sector firms listed in IDX during the period of 2013-2016.

\section{SUGGESTIONS}

For future work, it was suggested to conduct similar study in different sector with various samples and longer period of study (minimum of 5 years) to support results obtained in previous papers. Further study was also expected to add other variables which affect Dividend Policy and Firm Value in order to found more various result. For sampling selection, it was expected to pay more focus on firm sample that conduct successive dividend payout during the study period.

\section{REFERENCES}

1. Abreu, Jose Filipe and Mohamed Azzim Gulamhussen. 2013. Dividend payouts: Evidence from U.S. bank holding companies in the context of the financial crisis. Journal of Corporate Finance. Volume 22 pp 54-65.

2. Ameer, Rashid. (2008). Product market competition, regulation and dividend payout policy of Malaysian banks. Journal of Financial Regulation and Compliance. Vol. 16 Iss 4 pp. 318-334.

3. Asad, Muhammad and Saddia Yousaf. 2014. Impact of Leverage on Dividend Payment Behavior of Pakistani Manufacturing Firms. International Journal of Innovation and Applied Studies. Vol.6 No. 2 June 2014, pp 216-221.

4. Asif, Aasia, Waqas Rasool, and Yasir Kamal. (2011). Impact of financial leverage on dividend policy: Empirical evidence from Karachi Stock Exchange-listed companies. African Journal of Business Management. Vol. 5(4), pp. 1312-1324.

5. Brealey, Richard A., Stewarts C. Myers, dan Alan J. Marcus. 2008. Dasar-dasar Manajemen Keuangan Perusahaan, Penerbit Erlangga. Jakata.

6. Brigham, Eugene F. dan Joel F. Houston. 2001. Manajemen Keuangan edisi kedelapan buku 1, Penerbit Erlangga. Jakarta.

7. Bhattacharya, S. 1997. Imperfect Information, Devidend Policy and The Bird in The Hand Fallacy. Journal of Economics. Vol.10, pp. 259-27.

8. Ghozali, Imam. 2006. Structural Equation Modeling Metode Alternatif dengan Partial Least Square. Semarang: Badan Penerbit Universitas Diponegoro Semarang

9. Gill, Amarjit Ph.D and John D. Obradovich, Ph.D (2012). The Impact of Corporate Governance and Financial Leverage on the Value of American Firms. International Research Journal of Finance and Economics. ISSN 1450-2887 Issue 91.

10. Gitman, Lawrence J, 2006, Principles of Managerial Finance (11th ed.), Boston: Addison Wesley.

11. Gupta, Pradeep Kumar, Shailendra Kumar, and Piyush Verma. (2016). Association between Degree of Leverages and Firm Value. Asian Journal of Finance \& Accounting. Vol. 8 No.1.

12. Hamid, Rizwan, Muhammad Shahbaz Yaqub, Muhammad Mubashir Hussain Awan. (2016). Antecedents of Dividend Policy: Empirical Evidence from Banking Sector of Pakistan. European Online Journal of Natural and Social Sciences. Vol.5 No.2 pp.263274.

13. Irawati, Susan. 2006. Manajemen Keuangan, cetakan kesatu. Bandung. PT.Pustaka.

14. Javed, Muhammad Usman (2012). Impact of Financial Leverage on Dividend Policy: Case of Karachi Stock Exchange 30 Index. Journal of Contemporary Issues in Business Research. Volume 1, Issue No.1. 
15. Kasmir. 2012. Bank dan Lembaga Kuangan Lainnya. Jakarta: PT. Raja Grafindo Persada.

16. Kim, Soojung, Soon Hong Park, Jungwon Suh. 2016. AJ-shaped cross- sectional relation between dividends and firm value. Journal of Corporate Finance. Vol xxx.

17. Lestari, Jenjang Sri. 2012. Daterminants of Dividend Decision: Evidence from the Indonesia Stock Exchange. Review of Integrative Business \& Economics Research. Vol.1. No.1.

18. Margaretha, Farah. 2014. Dasar-dasar Manajemen Keuangan, PT. Dian Rakyat. Jakarta.

19. Ross, Stephen A. Westerfield, Radolp W. Brandford, Jordan. 2008. Corporate Finance Fundamental, Mc-GrawHill International Edition.

20. Sanusi, Anwar. 2011. Metodologi Penelitian Bisnis, Penerbit Salemba Empat. Jakarta.

21. Siboni, Zainab Morovvati and Mohammad Reza Pourali. (2015) The Relationship between Investment Opportunity, Dividend Policy and Firm Value in Companies Listed in TSE: Evidence from IRAN. European Online Journal of Natural and Social Sciences. Vol.4 no.1 ISSN 1805-3602.

22. Sugiyono, Prof. Dr. 2007. Metode Penelitian Bisnis, CV. Alfabeta. Bandung.

23. Tampubolon, Prof. Dr. Manahan P. 2013. Manajemen Keuangan (Finance Management), Penerbit Mitra Wacana Media. Jakarta.

24. Winarto, Jacinta. 2015. The Determinants of Manufacturer Firm Value in Indonesia Stock Exchange. International Journal of Information, Business and Management. Vol. 7 No. 4. 